\title{
Fish Identification based on Partial Fragments of The Mitochondrial COI Subunit I Gene
}

\author{
Tuah N. M. Wulandari $1^{*}$ \\ ${ }^{1}$ Research Institute for Inland Fisheries and Extension (RIIF-e) Palembang, BRSDM, KKP \\ Jl. Gub. H.A. Bastari 08 Palembang 30252, South Sumatera, Indonesia
}

\begin{abstract}
The mtDNA sequences revealed that several of the fish studied were Hampala macrolepidota and Barbonymus gonionotus. The objective of this research was to learn the pattern of COI gene in mtDNA and establish a phylogenetic tree. Basic Local Alignment Search Tool-nucleotide (BLASTn) confirmed that Barbonymus gonionotus from the Ranau Lake, South Sumatera has 100\% matching ranges to the species from Memberamo River (Indonesia), India, Bangladesh, Thailand (Mae Khlong), IndoMyanmar, and Malaysia_1. The lowest closeness (98.76\%) is related to species from Thailand (Lower Ing). The Blast investigation appears us that the level of familiarity was very high, it is coming to $98-100 \%$ in Barbonymus gonionotus. Hampala macrolepidota had 100\% matching ranges to the species from Indonesia (SouthaSumatera 1) and Vietnam. They had $99.05 \%-99.84 \%$ closeness from Malaysia_1,2\&3, Indonesia (South Sumatera_2\&3, Java and Bali_1,2\&3).
\end{abstract}

\section{Introduction}

Based on water volume, Ranau Lake is the second-largest the largest lake in Indonesia [15]. Some species that can be found in Ranau Lake are Hampala macrolepidota and Barbonymus gonionotus. Both belong to the family of cyprinidae. Although identifying the species by morphology has several limitations [13], molecular identification techniques have an advantage in rapid and accurate assessment [17]. COI-based on molecular method can identify specimens precisely, reliably, accessible, and at low cost [11]. DNA identification provides greater precision in species or lineage identification, including amplification and sequencing short mitochondrial COI genes [12]. Barbonymus gonionotus is very suitable as an ornamental fish. The population of this type of fish has experienced a decline in the last ten years due to logging, overfishing, and fishing practices that are not environmentally friendly by fishermen in the waters of Nagan [1]. Hampala macrolepidota has a black bar between the dorsal fin and pelvic fin in adult stages, which becomes less distinct in enormous specimens [5]. The study aims to identify several types of fishes using DNA sequences in the Ranau Lake and to obtain a more definite identification based on information on the nucleotide sequences of Barbonymus gonionotus and Hampala macrolepidota.

\section{Materials And Methods}




\subsection{Biological materials}

Barbonymus gonionotus and Hampala macrolepidota were collected using net and assistance from local fishermen. Three individuals of each type were obtained and stored in approximately $0.5 \mathrm{~cm} 2$ of solute $99 \%$ ethanol, placed in a test tube of $1.5 \mathrm{ml}$, and then kept in the refrigerator $\left(18^{\circ} \mathrm{C}\right)$.

\subsubsection{DNA extraction}

Genomic DNA was obtained by extracting each fish tissue (approximately $2.5 \mathrm{~mm}^{2}$ ). If a polymerase chain reaction (PCR) is to be used in extracting, the DNA sample should be kept in a freezer $\left(18^{\circ} \mathrm{C}\right)$.

\subsubsection{DNA amplification}

The DNA of Barbonymus gonionotus and Hampala macrolepidota was extracted and amplified using the following pairs of common primer COI-Fish-R and Fish-COI-F as follows: Fish COIF (5'ACT TCA AAC TTC CAY AAA GAY ATY GG-3') and COIFishR (5' TAG ACT TCT GGG TGG CCR AAR AAY CA-3') [7]. PCR carries out this DNA amplification. Genomic DNA extraction resulted in a COI gene fragment of $540 \mathrm{bp}$. Use Bioline's taq ReadyMix to perform PCR with a final volume of $50 \mu$ l. Each reaction contains $1 \mu 1$ FishF2 primer, $1 \mu 1$ FishR2 M primer, $21 \mu 1$ nuclease-free water, $25 \mu 1$ my taq ReadyMix and $2 \mu \mathrm{l}$ DNA template. The stage of pre-denaturation at $95^{\circ} \mathrm{C}$ for 1 minute, the second stage consists of 35 cycles, where each process is denatured at $95^{\circ} \mathrm{C}$ for 15 seconds, and direct bonding (annealing) to 55 Celsius degrees for 15 seconds, 72 Celsius degrees temperature extension for 30 seconds, the last stage of the form is 72 Celsius degrees final extension 3 minutes, and at a specific temperature $6^{\circ} \mathrm{C} 6$ minutes. In addition, the PCR products were run on a $120 \mathrm{v}, 250 \mathrm{~A}$ electrophoresis instrument for 5 minutes, and GelDoc was used for visualization. Use the $100 \mathrm{bp}$ marker [16] to observe PCR results of DNA size. The amplified DNA fragments were separated from an agarose gel (1\%) and stained with ethidium bromide.

\subsection{Data analysis}

The length of a DNA sequence of Barbonymus goninotus is $707 \mathrm{bp}$, and for Hampala macrolepidota is $680 \mathrm{bp}$. The results of nucleotide sequencing were manually edited using chromatogram-based Bioedit software [2]. In the next step, the MEGA 6.0 program (Molecular Evolutionary Genetics Analysis) [6] was used to align and modify the nucleotide sequence using Clustal W [4]. To determine DNA sequence similarity, the DNA sequence was transferred to BLASTn for nucleotide recovery. Data were provided by the National Center for Biotechnology Information (GenBank NCBI) used the neighbor-joining (NJ) method to align all the sequences of the phylogenetic tree.

\section{Results}

BLASTn evaluation confirmed that Barbonymus gonionotus from Lake Ranau in South Sumatra showed a $100 \%$ similarity level to the identical species from Memberamo River (Indonesia), India, Bangladesh, Thailand (Mae Khlong), Indo-Myanmar, Malaysia_1. The lowest similarity stage $(98.76 \%)$ was represented by the same species in Thailand (Lower Ing). The stage of similarity acquired from BLASTn analysis was very high, attaining 98$100 \%$ in Barbonymus gonionotus (Table 1). Hampala macrolepidota is $100 \%$ similar to sane 
species in Indonesia (South Sumatera_1) and Vietnam. Their similarities ranged from $99.05 \%$ to $99.8 \%$ in Malaysia_1, 2 and 3, Indonesia (South Sumatra_2 and 3, Java and Bali_1, 2 and 3) (Table 2).

Table 1. COI nucleotide of Barbonymus gonionotus based on BLASTn Method

\begin{tabular}{|c|c|c|c|c|}
\hline No & Classification & Compatibility (\%) & Accession number & Genesis \\
\hline 1 & Barbonymus gonionotus & 100 & KJ936769.1 & India \\
\hline 2 & Barbonymus gonionotus & 100 & MK572052.1 & Bangladesh \\
\hline 3 & Barbonymus gonionotus & 100 & MK902689.1 & Thailand (Mae Khlong) \\
\hline 4 & Barbonymus gonionotus & 100 & MG736407.1 & Indo-Myanmar \\
\hline 5 & Barbonymus gonionotus & 100 & MK970395.1 & IDN (Mamberamo) \\
\hline 6 & Barbonymus gonionotus & 100 & KT001016.1 & Malaysia_1 \\
\hline 7 & Barbonymus gonionotus & 98.76 & MK628326.1 & Thailand (Lower Ing) \\
\hline 8 & Barbonymus gonionotus & 99.41 & KT001015.1 & Malaysia_2 \\
\hline 9 & Barbonymus gonionotus & 100 & MK970394.1 & IDN (Memberamo_1) \\
\hline
\end{tabular}

Table 2. COI nucleotide of Hampala macrolepidota based on BLASTn Method

\begin{tabular}{|c|c|c|c|c|}
\hline No & Classification & $\begin{array}{c}\text { Compatibility } \\
(\mathbf{\%})\end{array}$ & Accession number & Genesis \\
\hline 1 & Hampala macrolepidota & 100 & KM213069.1 & IDN (South Sumatera_1) \\
\hline 2 & Hampala macrolepidota & 99,84 & KM213080.1 & IDN (South Sumatera_2) \\
\hline 3 & Hampala macrolepidota & 99,84 & KU692540.1 & IDN (Java and Bali_1) \\
\hline 4 & Hampala macrolepidota & 99,24 & JF781170.1 & Malaysia_1 \\
\hline 5 & Hampala macrolepidota & 99,43 & KU692541.1 & IDN (Java and Bali_2) \\
\hline 6 & Hampala macrolepidota & 99,35 & KT001059.1 & Malaysia_2 \\
\hline 7 & Hampala macrolepidota & 100 & MK116339.1 & Vietnam \\
\hline 8 & Hampala macrolepidota & 99,43 & KU692543.1 & IDN (Java and Bali_3) \\
\hline 9 & Hampala macrolepidota & 99,05 & KT001032.1 & Malaysia_3 \\
\hline
\end{tabular}

\section{Discussions}

Barbonymus goninotus and Hampala macrolepidota are divided into different branches in the phylogenetic tree (Figure 1). By the use bootstrap of Neighbor-Joining method, the results of phylogenetic tree analysis show there were two main groups, particularly Barbonymus gonionotus and Hampala macrolepidota. Hampala macrolepidota from Indonesia have been clustered with the same species from Malaysia and Vietnam, with a baseline value of $74 \%$. The starting value of Barbonymus goninotus and the same species from India, Bangladesh, Thailand, Indo-Myanmar, and Malaysia was 94\%. This species, Hampala macrolepidota, was distributed at upstream Mekong River/lower reaches Lancang River [8], Malaysia [7], and Lake Ranau in Indonesia [14]. 


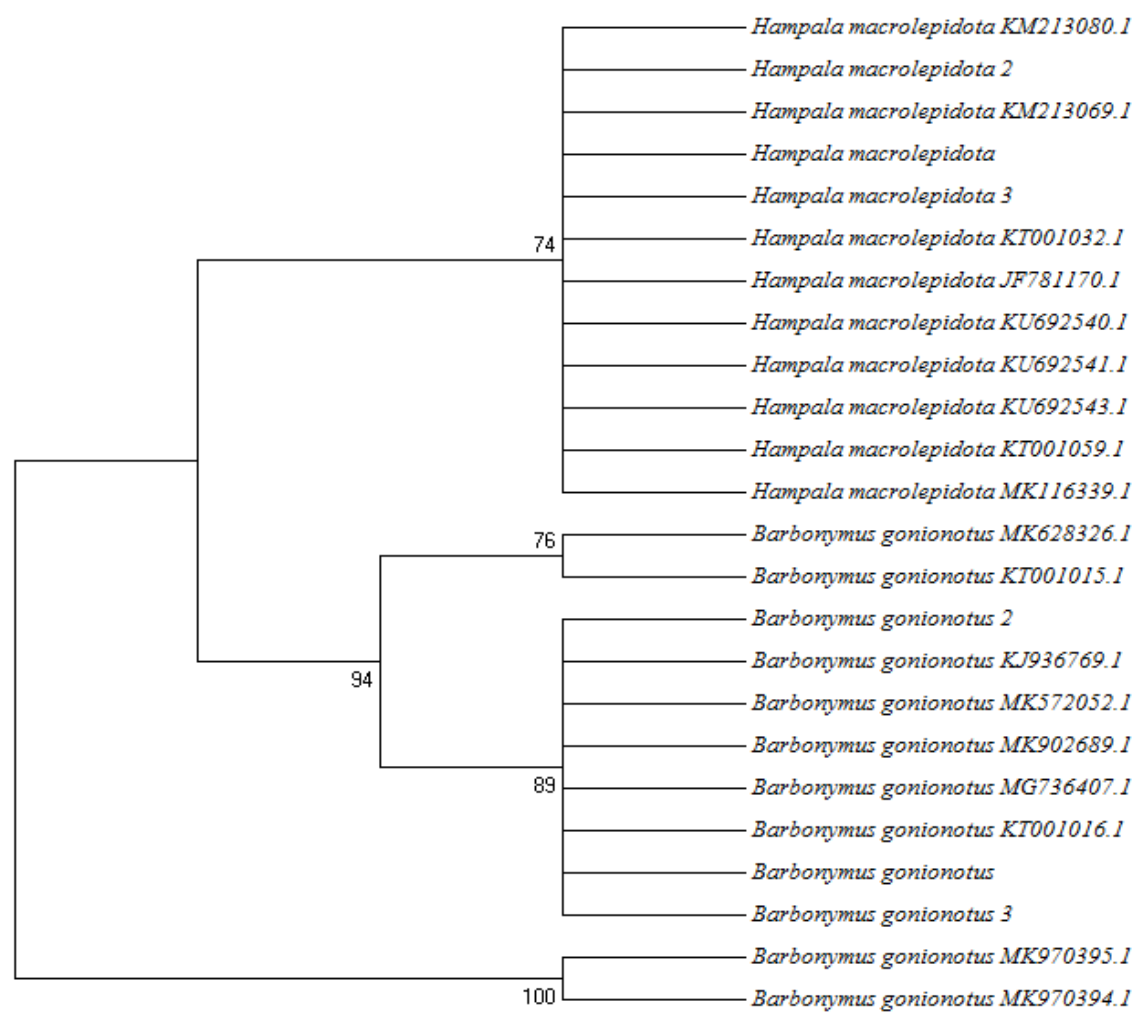

Fig. 1. Phylogenetic tree of Barbonymus gonionotus and Hampala macrolepidota by using the method of Neighbor-Joining (NJ) construction.

\section{Conclusion}

The length of the Barbonymus goninotus COI gene fragment is $707 \mathrm{bp}$, and the Hampala macrolepidota COI gene fragment length is $680 \mathrm{bp}$. Barbonymus goninotus is from Lake Ranau in South Sumatra and is $100 \%$ similar to the same species from the Memberamo River (Indonesia), India, Bangladesh, Thailand (Mae Khlong), Indo-Myanmar, and Malaysia_1. Hampala macrolepidota is $100 \%$ similar to the same species from Indonesia (South Sumatera_1) and Vietnam. Its similarities with Malaysia_1.2 and 3, Indonesia (South Sumatra_ $\overline{2}$ and 3, Java and Bali_1, 2, and 3) are 99.05\%-99. $\overline{84} \%$.

\section{Acknowledgment}

This scientific paper (KTI) contributes to the research activities of the Institute of Inland Fisheries and the Institute for Extension (RIIFe) Palembang, BRSDM, KKP.

\section{References}

1. A. S. Batubara, Z.A. Muchlisin, D. Efizon, R. Elvyra, M. Irham, Vestn. Zool. 53, 7582 (2019)

2. T. Hall, Nucleic Acids Symp. Ser. 41, 95-98 (1999) 
3. J. R. J. Ryan, Y.B. Esa, Zoolog. Sci. 23, 893-901 (2006)

4. J.D. Thompson, T.J. Gibson, F. Plewniak, F. Jeanmougin, D.G. Higgins, Nucleic Acid Res. 25, 4876-4882 (1997)

5. M. Kottelat, A.J. Whitten, S.N. Kartikasari, S. Wiroatmodjo, Freshwater fishes of Western Indonesia and Sulawesi (Periplus Editions, Singapore, 1993)

6. K. Tamura, G. Stecher, D. Peterson, A. Filipski, S. Kumar, Mol. Biol. Evol. 30, 27252729 (2013).

7. N. V. Ivanova, T.S. Zemlak, R.H. Hanner, P.D.N. Hebert, Mol. Ecol. Notes 7, 544-548 (2007).

8. M. Liu, F. Huang, S. Liu, Mitochondrial DNA A DNA Mapp. Seq. Anal. 26, 807-808. (2015).

9. M. Kimura, J. Mol. Evol. 16, 111-120 (1980).

10. Nei, M, Amer. Naturalist 106, 283-292 (1972).

11. P.D.N. Hebert, S. Ratnasingham, J.R. de Waard, Proc. R. Soc. Lond. B. Sci. 270, S96S99 (2003)

12. I. Parvez, T. Mahajebin, M.L. Clarke, M.S. Chhanda, S. Sultana, Ecol. Genet. Genom. 17, (2020).

13. R. Elvyra, D.D. Solihin, R. Affandi, M.Z. Junior, M. Suhendra, Biodiversitas 21, 35393546 (2020).

14. S. Makmur, D. Arfiati, G. Bintoro, A.W. Ekawati, J. Biodivers. Environ. Sci. 5, $447-$ 455 (2014)

15. Sulastri, M. Badjoeri, M.S. Syawal, LIMNOTEX 6, 25-38 (1999)

16. T. N. M. Wulandari, Herlan, A. Wibowo, S. Sawestri, BAWAL, 11, 33-44 (2019).

17. L. L. Wong, E. Peatman, J. Lu, H. Kucuktas, S. He, C. Zhou, U. Na-nakorn, Z. Liu, PLoS One 6, e17812 (2011). 